\title{
Randomized controlled clinical trial of two modality treatments for refractory wound seroma after modified radical mastectomy
}

\author{
Medhat Mohamed Anwara MD; Amr Alkobrosy,a MD; \\ Mohamed Atef Motawei,a MD; Mohamed Gaber Ibrahim,b MD
}

a) Department of Experimental and Clinical Surgery, Medical Research Institute. b) Department of Surgery, University of Alexandria.

\section{Introduction:}

Seroma formation is the most common complication following mastectomy) It's incidence after breast surgery varies between $2.5 \%$ and $51 \% .2$ Seroma is defined as a sterile accumulation of serum in a circumscribed location in the tissue. It develops at the operative site beneath the skin flaps during mastectomy or in the axillary dead space in the immediate or acute postoperative period. It is the result of tissue insult and the product of tissue inflammation and the body's defense mechanisms. Refractory seroma is the seroma which persists more than one month or high output drainage for long period. 3

Although seroma is not life threatening, it can lead to significant morbidity (e.g. flap necrosis, wound dehiscence, predisposes to sepsis, prolonged recovery period, multiple physician visits) and may delay adjuvant therapy. 4

Management options for seroma can be described as preventive or therapeutic. The former includes mechanical closure of dead space,s intraoperative administration of sclerosant6 or tissue glue into the wound cavity7and insertion of postoperative vacuum drains. 8 Therapeutic measures include percutaneous aspiration, 9 excision of the seroma capsule, 10 and administration of tissue gluell or sclerosant. 12

Mechanism of action of sclerotherapy is the induction of inflammatory response which leads to stimulation of fibroblasts leading to fibrosis and cavity obliteration.6 Tetracycline, ethyl alcohol 70\%,13 povidone iodine and erythromycin have been used as sclerosants. Topical tetracycline has been proved to be not effective in preventing post-mastectomy wound seromas.6 As regard erythromycin which is a common antibiotic, it was found to have a side effect in the form of irritation and inflammation at the site of injection if extravasation occurred It has been used safely in humans in the management of malignant pleural effusions 14 and non-neoplastic ovarian cysts.l 5 Povidone iodine has been used for chemical pleurodesis. 16 Success rates reported ranged from $64 \%$ to $100 \%$. Also, several groups have reported povidone iodine sclerotherapy for posttransplant lymphoceles.17

This study aims at the evaluation of the efficiency of two sclerosants; erythromycin and povidone iodine in the treatment of post modified radical mastectomy (MRM) refractory seroma in comparison to standard mechanical drainage using an indwelling catheter as a control group.

\section{Methods:}

Study design:

The study is a randomized controlled clinical trial.

Study setting:

The study was conducted in the Department of Surgery, Medical Research Institute, and the Main University Hospital, Faculty of Medicine, University of Alexandria, from beginning of June 2009 till end of October 2010.

Study population:

All patients suffering from postoperative mastectomy refractory seromas were included in the study. They were randomly divided into three groups of 20 patients each. In group A, complete aspiration of seroma by the way of a wide bore percutaneous cannula was done, followed by erythromycin injection in the seroma cavity (2gm in 40cc sterile water) and then the percutaneous cannula was removed. In group B, 10 to $30 \mathrm{ml}$ of diluted povidone iodine $10 \%$ solution (50\% povidone iodine 
and $50 \%$ saline) was administered by way of percutaneous catheter, which was inserted under local anesthesia in the most dependent part of the wound placed under ultrasound guidance. Patients were then instructed to irrigate the cavity 2 to 3 times daily with dilute povidone iodine solution at home, with a dwell time of 20 to 30 minutes. In group $\mathrm{C}$, the proposed treatment was just the insertion of the percutaneous catheter with local infiltration placed under ultrasound guidance. In group B and $\mathrm{C}$, catheters were removed later when output reached $<20 \mathrm{ml} / \mathrm{d}$.

Exclusion criteria included patients operated on with breast preservation procedures, patients with wound infection, patients with known or detected immediate hypersensitivity to erythromycin or to povidone iodine detected by intradermal test (done by injection ofO.lml of erythromycin or diluted povidone iodine intradermally in the forearm region and waiting for 20-30 minutes, the test was positive when redness and wheel appeared). IS

\section{Data collection procedure:}

Data were collected from the patients' records. For every patient, we obtained the following data: patient age, the onset of postoperative mastectomy seroma, the number of aspirations of sero:ma before treatment, the onset of treatment. Patients were followed-up for a minimum of 3 months in the outpatient clinic of the department of surgery. Post injection assessment included: Pain which was assessed using a linear visual analog pain score, 19 daily assessment of the amount of catheter drainage and clinical evaluation of seroma cavity 1week, 3 weeks , 6 weeks and 3 months later. The seroma cavity was assessed by ultrasound examination to the mastectomy bed after 3 weeks. The development of any wound infection during the follow up was also reported.

\section{Quality control:}

All the steps were done under the authors' supervision and followed standard procedures. All individuals agreed to participate after explaining the aims of the study and signed an informed consent. The study was approved by the Local Ethics Committee.

\section{Statistical analysis:}

Statistical analysis was performed using the Statistical Package for Social Sciences (SPSS version 17, Chicago, IL, USA). K-S test of Normality was done for quantitative data, which revealed not-normally distributed data so they were described using the median and range, while qualitative data were described using frequency and percent. For comparing more than two groups, Kruskal Wallis test was applied while followed by pairwise comparisons using multiple Mann-Whitney U test to compare between each 2 groups and significance level was adjusted after Bonferroni correction. Friedman ANOVA test used to compare quantitative data repeated more than 2 times. Comparing groups in qualitative data was done using the chi-square test but if invalid chi-square, the fisher's exact test was used for $2 \times 2$ tables and the Monte Carlo significance test for ( $\mathrm{r}$ x c) tables. All tests were two-sided and the significance level was set at 0.05 except in multiple pair wise comparison, the level of significance was adjusted after Bonferroni correction at (0.017).

\section{Power analysis:}

Power analysis is done using NCSS 2004 and PASS 2000 Program. Sample size of 20, 20,20 (tota160) achieves $86 \%$ power to detect difference among means of the volume of drained fluid between the 3 groups, assuming that the common standard deviation is 143 at level of significance 0.05 .

\section{Results:}

During the study period, we recruited a total of 60 female patients operated by modified radical mastectomy. The median age of the studied patients was 50 years (35-71 years). The median age of group I was 49 years, for group II was 50 years, while for group III was 49 years, without significant difference between the 3 groups Table(1).

The onset of seroma after removal of postmastectomy drains was between 15-67 days. The median in group A was 41 days (27- 67 days); in group B, it was 31.5 days (18- 49 days), while in group $\mathrm{C}$, it was 37 days (1559 days). This difference was found to be significant between group A and B $(\mathrm{p}=0.001)$, 
without significance difference between group $A$ and $C$ and between group B and C Table(l).

The number of aspirations of seroma before treatment was 2 to 5 aspirations. The sixty patients began the treatment after 31-98 days from the onset of seroma. In group A, it was between 31-44 days with a median of 37 days, in group B, it was between 34-62 days with a median of 43 days, while in group $C$, it was between 33-98 days with a median of 40 days Table(l).

In the follow up period, the volume of drained seroma is significantly reduced in each group over time. In group $\mathrm{A}$, the median drainage volume before treatment was $400 \mathrm{cc}$, decreased at one week of erythromycin injection to become $125 \mathrm{cc}$, and it decreased more to reach $25 \mathrm{cc}$ and $0 \mathrm{cc}$ at the $3 \mathrm{rd}$ and 6th week post-treatment respectively. This difference was found to be statistically significant $(p<0.05)$. In group $B$, the median drainage volume before treatment was $475 \mathrm{cc}$, it declined to reach $20 \mathrm{cc}$ at one week of povidone iodine treatment and it decreased more to reach $0 \mathrm{cc}$ and $0 \mathrm{cc}$, at the $3 \mathrm{rd}$ week and 6th week post-treatment respectively. This difference was found to be statistically significant $(p<0.05)$. Also, in group $C$, the median drainage volume before treatment was $425 \mathrm{cc}$. The volumes of drainage declined to reach 50 and 0, Occ at 1 st week, 3rd week, and 6th week respectively. This difference was found to be statistically significant $(\mathrm{p}<0.05)$ Table(2).

Inall groups, the median amounts of seroma fluid according to ultrasound examination (U/S) significantly decreased from before treatment to 3rd week of follow up. In group A, before treatment the median amounts of seroma fluid was $300 \mathrm{cc}$ and became $10 \mathrm{cc}$. In group $\mathrm{B}$, it was $375 \mathrm{cc}$ before treatment and became Occ and in group $\mathrm{C}$ the median was $325 \mathrm{cc}$ and became Occ at 3rd week. All differences were found to be statistically significant ( $\mathrm{p}<\mathrm{O} . \mathrm{OOl})$ Table $(3)$.

Ingroup $A$, the median VAS was 7 ranging from 6-9 out of 10; the pain was burning in nature, last for 2-3 days, responding to ibuprofen and paracetamol. In both groups B and $\mathrm{C}$, the median VAS was 1 ranging from $1-2$, so there was no need for analgesics. The
VAS in both groups $\mathrm{B}$ and $\mathrm{C}$ was significantly lower than group A ( $<<0.001)$ Table(4).

In our study, there were 5 cases of wound infection (infected seroma). The incidence in group A was 5\% (1 case). Ithappened on the 5th day post Erythromycin injection, there was turbid aspirate, it was sent to bacteriological analysis and the result was streptococcus pyogenus. It was sensitive to amoxicillinclavulanate potassium which was given and drain was inserted to drain the pus and was removed after 14 days. In group B and C, the incidence was $10 \%$ ( 2 cases) in each, it happened on the 4th day and 6th day from starting treatment in group B and it developed on the 5th and 6th days of drain insertion in group C. The color of drainage was turbid, povidone iodine was injected in both groups through the drain and amoxicillin - clavulanate potassium was given according to culture and sensitivity. The condition improved and the drain was removed on the 17th and 21st day in group Band on the 16th and 27th days in group C Table(5).

Catheter Drains were inserted in group B and $\mathrm{C}$. In group B, the median time of drain removal was 8th day ranging from 4-17 days, while in group $\mathrm{C}$ the median time of drain removal was 14th day ranging from 6-35 days, $(\mathrm{p}=0.002)$ Table $(6)$.

In group A, there were 8 cases of recurrent seroma after 3 months out of 20 cases in the follow up period, 3 of them were small amount 50-100cc treated with single aspiration, 2 cases were treated with 3 aspirations; each case repeated with an interval of one week. The volume of drainage ranged from 100-150cc on the first aspiration, while in the second aspiration the volume declined to reach 50$75 \mathrm{cc}$. The third aspiration volume reached $30-$ $35 \mathrm{cc}$ and in the remaining three cases the volume of drainage was 200-250cc. 3 aspirations were done but the drainage did not decline, so a new drain was inserted and povidone iodine was injected The drains were removed on 7 th, 1Oth, 12th days respectively. There was no recurrence of seroma. In group $\mathrm{B}$, there were 2 cases of recurrent seroma after 3 months out of 20 cases; the first case was treated with single aspiration, the volume of drainage was $80 \mathrm{cc}$ of seroma fluid. In the 
second case 2 repeated aspirations were done with 10 days interval, the volumes of drainage were 50 and $30 \mathrm{cc}$ respectively. In group C, there were 7 cases of recurrent seroma after 3 months out of 20 cases. 2 cases were treated with single aspiration, the volumes of drainage were 50-70cc. 3 cases were treated with 2 aspirations, in first aspirations the volumes of drainage were $70,100,120 \mathrm{cc}$ respectively of seroma fluid, in the second aspirations the volumes of drainage were $30,30,50 \mathrm{cc}$ respectively. 1 case was treated with 3 aspirations, the volumes were $200,100,30 \mathrm{cc}$ respectively. The last case was treated with reinsertion of a new drain after trials of 3 aspirations in which the volumes of drainage were $300,250,300 \mathrm{cc}$. Povidone iodine was injected through the drain. The drain was removed on the 14th day. There was no recurrence.

Table (1): Comparison between the three studied groups.

\begin{tabular}{|c|c|c|c|c|}
\hline & $\begin{array}{c}\text { Group A } \\
\text { \{erythromycin } \\
\text { injection) }\end{array}$ & $\begin{array}{c}\text { GroupB } \\
\text { \{povidone iodine } \\
\text { injection) }\end{array}$ & $\begin{array}{l}\text { Groupe } \\
\text { \{control) }\end{array}$ & $\begin{array}{c}x 2 \\
(p \text { value })\end{array}$ \\
\hline \multicolumn{5}{|l|}{ Age: } \\
\hline Range & $37-67$ & $42-71$ & $35-67$ & 0.99 \\
\hline Median & 49 & 50 & 49 & $\{0.610)$ \\
\hline \multicolumn{5}{|c|}{ Onset of seroma (days): } \\
\hline Range & $27-67$ & $18-49$ & $15-59$ & 10.6 \\
\hline Median & 41 & 31.5 & 37 & $\{0.004)$ \\
\hline pl & & $0.001 * *$ & 0.032 & \\
\hline $\mathrm{p} 2$ & & & 0.194 & \\
\hline \multicolumn{5}{|c|}{ Number of aspirations before treatment: } \\
\hline Range & $2-3$ & $2-5$ & $2-5$ & 2.19 \\
\hline Median & 2 & 2.5 & 2.0 & $\{0.334)$ \\
\hline \multicolumn{5}{|c|}{ Onset of treatment (days): } \\
\hline Range & $31-44$ & $34-62$ & $33-98$ & 11.06 \\
\hline Median & 38 & 43 & 37 & $(0.004)^{*}$ \\
\hline$z 1\{p)$ & & $3.094(0.002)^{* *}$ & $0.204(0.838)$ & \\
\hline$z 2\{p)$ & & & $2.622(0.009)^{* * *}$ & \\
\hline
\end{tabular}

Xz: Chi square for Kruskal Wallis test.

p1: $p$ value of Mann whitney $U$ test between group A and other groups.

p2: p value of Mann whitney $U$ test between group Band group $\mathrm{C}$.

*:Statistically significant at p0.05.

**Statistically significant at p0.017(after Bonferroni correction).

Z1: Zfor Mann Whitney test between group A and other groups.

Z2: Zfor Mann Whitney test between group Band group C. 
Table (2): Comparison between the three studied groups according to volume of drained seroma fluid before and after treatment at lrst, 3rd and 6th weeks.

\begin{tabular}{|c|c|c|c|c|}
\hline $\begin{array}{l}\text { Drainage } \\
\text { volume }\end{array}$ & $\begin{array}{c}\text { Group A } \\
\text { (erythromycin } \\
\text { injection) }\end{array}$ & $\begin{array}{l}\text { GroupB } \\
\text { (povidone iodine } \\
\text { injection) }\end{array}$ & $\begin{array}{l}\text { Group C } \\
\text { (control) }\end{array}$ & $\begin{array}{c}x ? \\
(p \text { value })\end{array}$ \\
\hline \multicolumn{5}{|l|}{ Before treatment: } \\
\hline Range & $150-850$ & $250-2500$ & $250-1000$ & 2.86 \\
\hline Median & 400 & 475 & 425 & $(0.239)$ \\
\hline \multicolumn{5}{|l|}{ At 1st week: } \\
\hline Range & $0-450$ & $0-50$ & $0-600$ & 22.23 \\
\hline & 125 & 20 & 50 & $(<0.001)^{*}$ \\
\hline$Z t(p)$ & & $4.436(<0.001)^{* *}$ & $1.225(0.221)$ & \\
\hline$Z 2(p)$ & & & $3.488(<0.001)^{* *}$ & \\
\hline \multicolumn{5}{|l|}{ AtJrdweek: } \\
\hline Range & $0-550$ & $0-150$ & $0-150$ & 6.47 \\
\hline Median & 25 & 0 & 0 & $(0.039)^{*}$ \\
\hline $\mathrm{Zt}(\mathrm{p})$ & & $2.368(0.018)^{*}$ & $1.716(0.086)$ & \\
\hline z2 (p) & & & $0.948(0.343)$ & \\
\hline \multicolumn{5}{|l|}{ At 6th week: } \\
\hline Range & $0-300$ & $0-100$ & $0-400$ & 5.786 \\
\hline $\begin{array}{l}\text { Median } \\
\qquad X^{2} \operatorname{Fr}(n)\end{array}$ & $\begin{array}{c}0 \\
425<0001) *\end{array}$ & $\begin{array}{c}0 \\
476(<0001) *\end{array}$ & $\begin{array}{c}0 \\
509(<0.001) *\end{array}$ & $(0.055)$ \\
\hline$X^{2} \mathrm{Fr}$ & $42.5\{<0.001)^{*}$ & $47.6(<0.001)^{*}$ & $50.9(<0.001)^{*}$ & \\
\hline
\end{tabular}

Xz: Chi square for Kruskal Wallis test.

$Z t$ : Zfor Mann Whitney test between group A and other groups.

Zt: Zfor Mann Whitney test between group Band group $C$.

$\mathrm{X}^{2} \mathrm{Fr}$ : Chi square for FriedmanANOVA test.

* : Statistically significant at p0.05.

**Statistically significant at $p<0.017$ (after Bonferroni correction). 
Table (3): Comparison between the amounts ofseromajluid in the three studied groups according to ultrasound examination (U/S) to mastectomy bed before treatment and at the Jrd week of foUow up.

\begin{tabular}{|c|c|c|c|c|}
\hline $\begin{array}{l}\text { Amount of } \\
\text { Seroma by U/S }\end{array}$ & $\begin{array}{c}\text { Group A } \\
\text { (erythromycin } \\
\text { injection) }\end{array}$ & $\begin{array}{l}\text { GroupB } \\
\text { (povidone iodine } \\
\text { injection) }\end{array}$ & $\begin{array}{l}\text { Group C } \\
\text { (control) }\end{array}$ & $\begin{array}{c}x ? \\
(p \text { value })\end{array}$ \\
\hline \multicolumn{5}{|l|}{ Before treatment: } \\
\hline Range & $100-750$ & $150-600$ & $200-700$ & 0.341 \\
\hline Median & 300 & 375 & 325 & \\
\hline \multicolumn{5}{|l|}{ 3rdweek: } \\
\hline Range & $0-400$ & $0-150$ & $0-250$ & 0.052 \\
\hline Median & 10 & 0 & 0 & \\
\hline $\mathrm{Z}(\mathrm{p})$ & $3.692(<0.001)^{*}$ & $3.932(<0.001)^{*}$ & $3.931(<0.001)^{*}$ & \\
\hline
\end{tabular}

X\}: Chi square for Kroskal Wallis test.

$Z: Z$ for Wilcoxon signed ranks test between preoperative and at the $3 r d$ week.

*:Statistically significant at p0.05.

Table (4): Comparison between the three studied groups according to post-injection pain.

\begin{tabular}{|c|c|c|c|c|}
\hline $\begin{array}{l}\text { Pain at } \\
\text { injection site }\end{array}$ & $\begin{array}{c}\text { Group A } \\
\text { (erythromycin } \\
\text { injection) }\end{array}$ & $\begin{array}{c}\text { GroupB } \\
\text { (povidone iodine } \\
\text { injection) }\end{array}$ & $\begin{array}{c}\text { Groupe } \\
\text { (control) }\end{array}$ & $\begin{array}{c}\text { X.Z } \\
(p \text { value })\end{array}$ \\
\hline $\begin{array}{c}\text { Range } \\
\text { Median }\end{array}$ & $6-9$ & $1-2$ & $1-2$ & 1 \\
Zt $(p)$ & 7 & 1 & $(<0.001)^{*}$ \\
Z2 (p) & & $5.540(<0.001)^{* *}$ & $\begin{array}{c}5.629(<0.001)^{* *} \\
1.363(0.173)\end{array}$ & \\
\hline
\end{tabular}

"I]: Chi square for Kroskal Wallis test.

Z1: Zfor Mann Whitney test between group A and other groups.

Z2: Zfor Mann Whitney test between group Band group C.

* : Statistically significant at p0.05.

**:Statistically significant at p0.017(after Bonferroni correction).

Table (5): Comparison between the three studied groups according to wound infection.

\begin{tabular}{|l|cc|cc|cc|c|}
\hline $\begin{array}{l}\text { Wound } \\
\text { Infection }\end{array}$ & \multicolumn{2}{|c|}{$\begin{array}{c}\text { Group A } \\
\text { (erythromycin } \\
\text { injection) }\end{array}$} & $\begin{array}{c}\text { GroupB } \\
\text { (povidone iodine } \\
\text { injection) }\end{array}$ & \multicolumn{2}{|c|}{$\begin{array}{c}\text { Groupe } \\
\text { (control) }\end{array}$} & MCp \\
\hline no. & $\%$ & no. & $\%$ & no. & $\%$ & \multirow{2}{*}{1000} \\
No & 19 & $(95)$ & 18 & $(90)$ & 18 & $(90)$ \\
Yes & 1 & $(5)$ & 2 & $(10)$ & 2 & $(10)$ & \\
\hline
\end{tabular}

MCp: $p$ for Monte Carlo significance test. 
Table (6): Comparison between group B and $C$ according to time of drain removal after treatment of seroma.

\begin{tabular}{|l|c|c|c|}
\hline $\begin{array}{l}\text { Drain } \\
\text { removal } \\
\text { time }\end{array}$ & $\begin{array}{c}\text { GroupB } \\
\text { (povidone iodine } \\
\text { injection) }\end{array}$ & $\begin{array}{c}\text { Group C } \\
\text { (control) }\end{array}$ & $\begin{array}{c}\mathrm{Z} \\
(\mathrm{p})\end{array}$ \\
\hline $\begin{array}{l}\text { Range } \\
\text { Median }\end{array}$ & $\begin{array}{c}4-17 \\
8\end{array}$ & $\begin{array}{c}6-35 \\
14\end{array}$ & $\begin{array}{c}3.143 \\
(0.002)^{*}\end{array}$ \\
\hline
\end{tabular}

Z: Z for Mann Whitney test between group B and group $C$.

*:Statistically significant at p0.05.

Table (7): Comparison between the three studied groups according to the recu"ence of seroma after 3 months of complete treatment of seroma.

\begin{tabular}{|c|cc|cc|cc|c|}
\hline $\begin{array}{l}\text { Follow up at } \\
\text { 3rdmonth }\end{array}$ & $\begin{array}{c}\text { Group A } \\
\text { (erythromycin } \\
\text { injection) }\end{array}$ & $\begin{array}{c}\text { GroupB } \\
\text { (povidone iodine } \\
\text { injection) }\end{array}$ & \multicolumn{2}{|c|}{$\begin{array}{c}\text { Groupe } \\
\text { (control) }\end{array}$} & y,Z (p) \\
\hline & no. & $\%$ & no. & $\%$ & no. & $\%$ & \\
\hline $\begin{array}{c}\text { No seroma } \\
\begin{array}{c}\text { Recurrence } \\
\text { ofseroma }\end{array}\end{array}$ & 12 & $(60)$ & 18 & $(90)$ & 13 & $(65)$ & $5.089(0.079)$ \\
\end{tabular}

$\cdot x\}$ : Chi square test.

\section{Discussion:}

MRM was associated with a higher rate of postoperative seroma formation.4 Seroma management should be considered early because of the tendency to develop complications and impair quality of life. Indication for sclerotherapy primarily consisted of recurrent seroma despite failed aspiration.

In this study, there was no statistical significant difference regarding the number of aspirations of seroma before treatment between the three groups $(p=0.33)$. This result was comparable to the results reported by Throckmorton,13 and Ali-Khan,12 where the range of aspirations was 1-5 and 2-7, respectively. Also, when we compare the volumes of drained seroma before treatment, there was no statistical significant difference between the three studied groups $(\mathrm{p}=0.239)$. But at the end of the 1st week from starting treatment, there was statistically significant decline in the volume of drained seroma in group B than groups A $(\mathrm{p}<\mathrm{O} . \mathrm{OOI})$ and $\mathrm{C}$ $(p<O . O O I)$, with no statistical significant difference between groups $\mathrm{A}$ and $\mathrm{C}(\mathrm{p}=0.221)$. Also at the 3rd week of follow up there was statistically significant difference in the volume of drained seroma between groups A and B $(p=0.018)$. Povidone iodine injection was significantly effective in seroma volume reduction than erythromycin injection. illtrasound examination to mastectomy bed at the 3rd week of follow up confirmed also the good response of patients in groups $\mathrm{B}$ and $\mathrm{C}$ than group A. This difference was found to be of borderline significance $(\mathrm{p}=0.052)$. In each group separately, there is a significant reduction of the drained amount of seroma both clinically and by U/S before and after treatment, $\mathrm{p}<0.05$.

In the work of Throckmorton, 13 the mean volume of drainage across all patients in this series was $105 \mathrm{cc}$ (20 to $310 \mathrm{cc}$ ) which was decreasing till complete cure by the 4th week. In this study ninety-five percent ethyl alcohol or povidone iodine was used as sclerotherapy. In the work of Ali Khan et al,12 the mean volume of drainage before treatment was 385 $\mathrm{cc}$ ranging from $170-1200 \mathrm{cc}$, the three out of 
four patients were completely free on the follow up, and the average volume of 4th patient on follow up was 68 ranging from 50-200cc. In this study erythromycin was used as sclerotherapy.

The severity of pain on injecting erythromycin was from moderate to severe. The median VAS was 7 (6-9), the pain was burning in nature, lasted for 2-3 days and responded to ibuprofen and paracetamol. The pain was due to severe irritation of the nerve endings. The pain in group $\mathrm{B}$ and $\mathrm{C}$ was in the form of mild severity (VAS was 1 ranging from 1-2) and there was no need for analgesics. This difference was found to be statistically significant $(\mathrm{p}<\mathrm{O} . \mathrm{OO})$. In the work of Throckmorton et al,13 minor degree of pain was reported. In the work of Ali khan,12 there was some discomfort that had persisted for 72 hrs but was controlled with paracetamol and ibuprofen.

Despite the presence of drains inboth groups $\mathrm{B}$ and $\mathrm{C}$, the rate of wound infection in both groups was not significantly different from that of group A. The incidence in group A was $5 \%$ ( 1 case), while the incidence in groups $\mathrm{B}$ and $\mathrm{C}$ was $10 \%$ ( 2 cases) in each. In the work of Throckmorton,13 43\% developed an infection at a median of 11 days (range 4 to 29) after the initiation of sclerotherapy treatment, while in the work of Ali khan, 12 no wound infection was developed.

A good point in our study is the early removal of drains in group $\mathrm{B}$ in comparison to group C (8th day versus 14th day, respectively) and this difference was found to be statistically significant $(p==0.002)$. The uses of povidone iodine significantly decrease the time of drain removal. In Throckmorton study, 13 the total median treatment duration was 16 days (range 6 to 41 ).

The incidence of seroma recurrence in group $\mathrm{B}$ was $10 \%$, which was lower than groups $\mathrm{A}$ and $\mathrm{C}$ (40 and $35 \%$ respectively), but this difference doesn't reach to the level of significance. In the work of Throckmorton,13 treatment was successful in 15 of $18(83 \%)$ patients; 3 seromas recurred and were effectively treated with a single aspiration, while in the work of Ali-Khan et al,12 treatment was successful in 3 patients while in the last one 8 aspirations were performed till complete cure. Recurrent seroma was treated in most of our cases with repeated aspirations except in 4 patients (3 in group A and 1 in group C) where drain reinsertion was applied and povidone iodine was injected.

Our study has several limitations; seroma formation was not studied in relation to the predisposing factors to its formation as age of the patient, breast volume, nodal involvement, preoperative chemotherapy, surgical instrument (electrocautery or scalpel), use of pressure garment and duration of drainage. Although in a previous study4 no relationship was observed between the incidence of seroma and the patients' age, tumour size, and lymph node status. But in Gonzalez study,20 they showed that there was a direct correlation between age and the development of seroma. In Loo and Chow study, ${ }^{21}$ the presence of hypertension in a patient over 45 years should alert the surgeon to possible seroma formation, particularly when the post-operative drainage exceeded $500 \mathrm{ml}$ in the first three days.

In conclusion, sclerotherapy is a feasible treatment for refractory seroma after MRM. The results of our study suggest that povidone iodine injection in patients with seroma after MRM is an alternative solution in treating safely and rapidly refractory seroma with less recurrence and less pain. Longer treatment duration was associated with infection; antibiotic prophylaxis should be considered.

\section{References:}

1- Chilson TR, Chan FD, Lonser RR, Wu TM, Aitken DR: Seroma formation after modified radical mastectomy. Am Surg 1992; 58: 750-754.

2- Woodworth PA, McBoyle MF, Helmer SD, Beamer RL:Seroma formation after breast cancer surgery: Incidence and predicting factors. Am Surg 2000; 66: 444-450.

3- Kuroi K, Shimozuma K, Taguchi T, Imai H, Yamashiro H, Ohsumi S, Saito S: Pathophysiology of seroma in breast cancer. Breast Cancer 2005; 12(4): 288-293.

4- Hashemi E, Kaviani A, Najafi M, Ebrahimi M, Hooshmand H, Montazeri A: Seroma formation after surgery for breast cancer. Breast Cancer 2004; 9(2): 44. 
5- Kuroi K, Imai H, Yamashiro H, Ohsumi S, Saito S: Effect of mechanical closure of dead space on seroma formation after breast surgery. Breast Cancer 2006; 13(3): 260265.

6- Rice DC, Morris SM, Sarr MG, Farnell MB, van Heerden JA, Grant CS, Rowland CM, Ilstrup DM, Donohue JH: Intraoperative topical tetracycline sclerotherapy following mastectomy: A prospective, randomized trial. J Surg Oncol2000; 73(4): 224-227.

7- Carless PA, Henry DA: Systematic review and meta-analysis of the use of fibrin sealant to prevent seroma formation after breast cancer surgery. Br J Surg 2006; 93(7):810819.

8- Chintamani, Singhal V, Singh J, Bansal A, Saxena S: Halfversus full vacuum suction drainage after modified radical mastectomy for breast cancer- a prospective randomized clinical trial. BMC Cancer 2005; 5: 11.

9- Wiener M, Mackie I, Ralston DR: Drainage of large or symptomatic seromas: Let the vacuum do the work. J Plast Reconstr Aesthet Surg 2007; 60(5): 573-574.

10-Stanczyk M, Grala B, Zwierowicz T, Maruszynski M: Surgical resection for persistent seroma, following modified radical mastectomy. World J Surg Oneal 2007; 5: 104.

11-Butler CE: Treatment of refractory donorsite seromas with percutaneous instillation of fibrin sealant. Plast Reconstr Surg 2006; 117(3): 976-985.

12-Ali-Khan AS, Orlando A, Kenealy J: Erythromycin sclerotherapy in the management of seroma. J Plast Reconstr Aesthet Surg 2009; 62(3): 55-58.
13-Throckmorton AD, Askegard-Giesmann J, Hoskin TL, Bjarnason H, Donohue JH, Boughey JC, Degnim AC: Sclerotherapy for the treatment of postmastectomy seroma.AmJSurg2008; 196(4): 541-544.

14-Tang $X$, Cheng D: The value of erythromycin pleurodesis in the treatment of malignant pleural effusions.J West China Univ Med Sci 1997; 28: 437-439.

15-Kafali H, Yurtseven S, Atmaca F: Management of non-neoplastic ovarian cysts with sclerotherapy. Int J Gynaecol Obstet 2003; 81: 41-45.

16-Agarwal R, Aggarwal AN, Gupta D: Efficacy and safety of iodopovidone pleurodesis through tube thoracostomy. Respirology 2006; 11: 105-108.

17-Rivera M, Marcen R. Burgos J, Arranz M, Rodriguez R, Teruel JL, Ortufio J: Treatment of posttransplant lymphocele with povidone-iodine sclerosis: Long-term follow-up. Nephron 1996; 74: 324-327.

18-Brockow K, Romano A, Aberer W, et al: Skin testing in patients with hypersensitivity reactions to iodinated contrast media: A European multicenter study. Allergy 2009; 64(2): 234-241.

19-Revill SI, Robinson JO, Rosen M, Hogg MI: The reliability of a linear analogue for evaluating pain. Anaesthesia 1976; 31(9): 1191-1198.

20-Gonzalez EA, Saltzstein EC, Riedner CS, Nelson BK: Seroma formation following breast cancer surgery. Breast J 2003; 9: 385-388.

21-Loo WT, Chow LW: Factors predicting seroma formation after mastectomy for Chinese breast cancer patients. Indian $J$ Cancer 2007; 44: 99-103. 